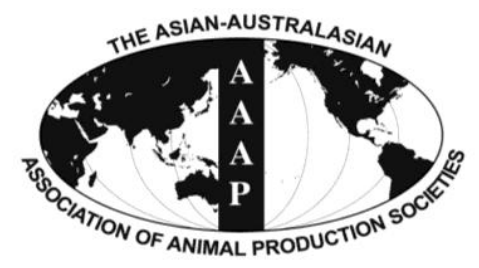

Asian Australas. J. Anim. Sci.

Vol. 26, No. 9 : 1320-1328 September 2013

http://dx.doi.org/10.5713/ajas.2013.13200

www.ajas.info

pISSN 1011-2367 elSSN 1976-5517

\title{
Effects of Single Cell Protein Replacing Fish Meal in Diet on Growth Performance, Nutrient Digestibility and Intestinal Morphology in Weaned Pigs
}

\author{
H. Y. Zhang, X. S. Piao*, P. Li, J. Q. Yi, Q. Zhang, Q. Y. Li, J. D. Liu, and G. Q. Wang \\ Ministry of Agriculture Feed Industry Centre, State Key Laboratory of Animal Nutrition, \\ China Agricultural University, Beijing 100193, China
}

\begin{abstract}
Three experiments were conducted to evaluate the ME value, standardized ileal digestibility (SID) of amino acids (AA) of fish meal, and the effects of single cell protein (Prosin and Protide) replacing fish meal in diet on growth performance, nutrient digestibility and intestinal morphology in weaned piglets. In Exp. 1, twenty-four barrows with initial BW of $30.8 \pm 2.6 \mathrm{~kg}$ were allotted to one of four dietary treatments. Diet 1 contained corn as the only energy source. The other three diets replaced $20 \%$ of the corn in diet 1 with one of the three protein feeds (fish meal, Prosin and Protide), and the DE and ME contents were determined by difference. In Exp. 2, eight barrows (initial BW of $25.6 \pm 3.2 \mathrm{~kg}$ ) were fitted with ileal T-cannulas and allotted to a replicated $4 \times 4$ Latin square design. Three cornstarch-based diets were formulated using each of the protein feeds as the sole source of AA. A nitrogen-free diet was also formulated to measure endogenous losses of AA. In Exp. 3, one hundred and eighty piglets (initial BW of $7.95 \pm 1.59 \mathrm{~kg}$ ) weaned at $28 \pm 2 \mathrm{~d}$ were blocked by weight and assigned to one of five treatments for a 28 -d growth performance study, each treatment was fed to six pens with six pigs (three barrows and three gilts) per pen. The five treatments consisted of the control group (CON), which was a corn-soybean meal diet containing 5\% fish meal, and the other four treatments, which replaced a set amount of fish meal with either Prosin $(2.5 \%$ or $5 \%)$ or Protide $(2.5 \%$ or $5 \%)$. The diets were formulated to provide same nutrient levels. The results showed that on a DM basis, both of the DE and ME contents were lower in Prosin and Protide than that of fish meal $(\mathrm{p}<0.05)$. The SID of CP and all essential AA were greater in fish meal than in Prosin and Protide $(\mathrm{p}<0.05)$. The pigs fed CON diet had greater weight gain and lower feed conversion rate (FCR) than pigs fed 5\% Prosin and 5\% Protide diets $(\mathrm{p}<0.05)$. The digestibility of CP was greater in pigs fed CON, 2.5\% Prosin and 2.5\% Protide diets than the pigs fed 5\% Prosin and 5\% Protide diets $(\mathrm{p}<0.05)$. Villus height in jejunum and ileum, and villus height to crypt depth ratio in the jejunum were higher $(\mathrm{p}<0.05)$ in pigs fed CON, $2.5 \%$ Prosin and $2.5 \%$ Protide diets compared with the 5\% Prosin and 5\% Protide diets. Pigs fed CON diet had greater villus height to crypt depth ratio in the ileum than the pigs fed 5\% Prosin and 5\% Protide diets ( $\mathrm{p}<0.05)$. In conclusion, although Prosin and Protide contained lower ME content and SID of AA than fish meal, Prosin and Protide replacing 50\% of fish meal in diet with identical nutrient levels could obtain similar performance, nutrient digestibility and intestinal morphology in weaned pigs. (Key Words: Single-cell Protein, Fish Meal, Performance, Nutrient Digestibility, Intestinal Morphology, Weaned Pigs)
\end{abstract}

\section{INTRODUCTION}

Single-cell protein (SCP) refers to the dried cells of microorganisms such as yeasts, bacteria, fungi and microalgae, grown in large-scale culture systems for use as protein sources in human food or animal feed (Zepka et al., 2010; Wang et al., 2013). Compared to fish meal, most sources of SCP (from bacteria and yeast) have similar lysine (Lys), methionine (Met) and cysteine (Cys) content, and a

\footnotetext{
* Corresponding Author: X. S. Piao. Tel: +86-10-62733588, Fax: +86-10-62733688, E-mail: piaoxsh@mafic.ac.cn Submitted Apr. 10, 2013; Accepted Jun. 17, 2013; Revised Jul. 10, 2013
}

higher proportion of tryptophan (Trp) and threonine (Thr) (Skrede et al., 1998). There are not only proteins, but also contributes free amino acids, lipids, carbohydrates, vitamins and minerals in SCP (Anupama and Ravindra, 2000).

Production of SCP using waste materials as substrate, provides an economically feasible protein source that is useful in animal feed and products for human consumption as it often meets dietary requirements for protein (Kuhad et al., 1997). Algae, fungi and bacteria are the chief sources of microbial protein that can be utilized as SCP (Anupama and Ravindra, 2000). In general, high production rates and protein yields as well as ease of production control make 
SCP more attractive as a protein source compared with conventional plant and animal origins (Paraskevopoulou et al., 2003).

The SCP can be a protein source that offers a potential alternative to fish meal, meat and bone meal, soybean meal, and other protein sources in animal nutrition (Hellwing et al., 2007b). Certain amounts of traditional protein sources can be substituted by SCP without impairment to the performance of pigs (Braude et al., 1977; Hanssen and Farstad, 1980). Previous studies showed that up to $40 \%$ $20 \%$ (chickens), and 50\% (pigs) of dietary $\mathrm{N}$ could be replaced by SCP without affecting nitrogen retention, heat production, and energy retention (Hellwing et al., 2005; 2006; 2007a).

Prosin and Protide are two kinds of SCP, by-products of the production of lysine and nucleotide fermented from cornstarch by Corynebacterium glutamicum. As new sources of protein, information regarding their nutritional value and effects on pig performance are limited. Therefore, the objectives of the current experiment were to determine the ME content as well as standardized ileal digestibility (SID) of AA in Prosin and Protide, based on the ME and SID of AA values, to evaluate the effects of Prosin and Protide replacing $50 \%$ or $100 \%$ of fish meal in diet with identical nutrient levels on growth performance, nutrient digestibility and intestinal morphology in weaned piglets.

\section{MATERIALS AND METHODS}

The experimental protocols were approved by the Institutional Animal Care and Use Committee (IACUC) of China Agricultural University (Beijing, China). The fish meal used in this study was commercial supplied (Pesquera Diamante S. A., Peru), and Prosin and Protide were supplied by CJ Co. Ltd., (Liaocheng, China). Briefly, after pure L-Lysine or nucleotide was removed from the Corynebacterium glutamicum fermentation medium, the live bacteria was killed in high temperature, then the left medium was dried to produce Prosin and Protide. The analyzed chemical composition of Prosin and Protide is shown in Table 1.

\section{Animals and experimental design}

Experiment 1: Twenty four barrows (Duroc $\times$ Landrace $\times$ Large White) with initial BW of $30.8 \pm 2.6 \mathrm{~kg}$ were used to determine the DE and ME contents of fish meal, Prosin and Protide. Pigs were allotted to one of four experimental treatments, each treatment was fed to six pens with one pig per pen. The basal diet containing corn as the only energy source $(96.31 \%$ corn and $3.69 \%$ minerals and vitamins) and this diet was used to determine the DE and ME content of corn. In the remaining three diets, $20 \%$ of the corn was substituted with fish meal, Prosin and Protide respectively
Table 1. Analyzed nutrient composition of fish meal and singlecell proteins (Prosin and Protide) (as-fed basis)

\begin{tabular}{lccc}
\hline Item $(\%)$ & Fish meal $^{1}$ & Prosin $^{2}$ & Protide $^{2}$ \\
\hline DM & 88.83 & 94.09 & 95.99 \\
Gross energy (kcal/kg) & 4,710 & 4,784 & 5,164 \\
$\mathrm{CP}$ & 66.03 & 70.03 & 57.53 \\
$\mathrm{EE}$ & 1.72 & 8.23 & 7.44 \\
$\mathrm{Ca}$ & 3.42 & 0.04 & 0.01 \\
$\mathrm{P}$ & 2.42 & 0.39 & 1.63 \\
Essential AA & & & \\
Arginine & 3.49 & 3.28 & 2.61 \\
Histidine & 2.34 & 1.26 & 0.96 \\
Isoleucine & 2.69 & 2.45 & 2.35 \\
Leucine & 4.54 & 4.23 & 4.28 \\
Lysine & 4.97 & 8.23 & 1.97 \\
Methionine & 1.63 & 0.98 & 1.47 \\
Phenylalanine & 2.50 & 2.15 & 2.49 \\
Threonine & 2.62 & 2.86 & 2.61 \\
Tryptophan & 0.65 & 0.58 & 0.73 \\
Valine & 2.93 & 3.34 & 3.55 \\
Nonessential AA & & & \\
Alanine & 3.83 & 5.31 & 5.35 \\
Asparagine & 5.63 & 5.44 & 5.57 \\
Cystine & 0.84 & 0.32 & 0.26 \\
Glutamine & 6.92 & 8.05 & 8.35 \\
Glycine & 3.82 & 2.61 & 2.81 \\
Proline & 2.54 & 1.87 & 1.83 \\
Serine & 2.16 & 2.18 & 2.37 \\
Tyrosine & 1.88 & 1.40 & 1.13 \\
\hline
\end{tabular}

${ }^{1}$ Fish meal (Commercial supply).

${ }^{2}$ Prosin and Protide (CJ Co. Ltd., Liaocheng, China).

at the expense of corn, the energy values were determined by differences on the assumption that their contributions were additive (Woodworth et al., 2001). The diets were shown in Table 2.

Pigs were fed with two equal meals twice daily at 8:00 h and 17:00 $\mathrm{h}$ and had free access to water throughout the trial. Daily feed allowance was equivalent to $4 \%$ of body weight and was fed in mash form. Each feeding period consisted of $5 \mathrm{~d}$ for diet adaptation, followed by $5 \mathrm{~d}$ of total collection of feces and urine. In the morning meal on $\mathrm{d} 6$ and $9,1 \mathrm{~g}$ of chromic oxide was mixed into the meal and used as a fecal marker. Feces collection from each pig was initiated with the first appearance of the marker in the feces after d 6 and collection ceased when the marker first appeared in the feces after d 9 (Petersen and Stein, 2006). Feces were collected twice daily, weighed, composited for each pig, and stored at $-20^{\circ} \mathrm{C}$; Urine was collected in a bucket placed under the metabolic crate containing $50 \mathrm{~mL}$ of $6 \mathrm{~N} \mathrm{HCl}$ as a preservative, urine collection was stored at $-20^{\circ} \mathrm{C}$ until subsequent analysis (Adeola and Bajjalieh, 1997). 
Table 2. Ingredient composition of experimental diets containing fish meal and single-cell proteins (Prosin and Protide) (as-fed basis), Exp. 1

\begin{tabular}{|c|c|c|c|c|}
\hline Ingredient $(\%)$ & Corn & $\begin{array}{c}\text { Fish } \\
\text { meal }^{1}\end{array}$ & Prosin ${ }^{2}$ & Protide $^{2}$ \\
\hline Corn & 96.31 & 76.31 & 76.31 & 76.31 \\
\hline Fish meal $(66.03 \% \mathrm{CP})$ & - & 20.00 & - & - \\
\hline Prosin $(70.03 \% \mathrm{CP})$ & - & - & 20.00 & - \\
\hline Protide $(57.53 \% \mathrm{CP})$ & - & - & - & 20.00 \\
\hline Limestone & 0.66 & 0.66 & 0.66 & 0.66 \\
\hline Dicalcium phosphate & 1.68 & 1.68 & 1.68 & 1.68 \\
\hline Salt & 0.35 & 0.35 & 0.35 & 0.35 \\
\hline Vitamin-mineral premix ${ }^{3}$ & 1.00 & 1.00 & 1.00 & 1.00 \\
\hline \multicolumn{5}{|c|}{$\begin{array}{l}{ }^{1} \text { Fish meal (Commercial supply). } \\
{ }^{2} \text { Prosin and Protide (CJ Co. Ltd., Liaocheng, China). } \\
{ }^{3} \text { Premix supplied per kg diet: vitamin A, 12,000 IU; vitamin } \mathrm{D}_{3}, 1,500 \mathrm{IU} \text {; } \\
\text { vitamin E, } 44.1 \mathrm{IU} \text {; menadione, } 4.0 \mathrm{mg} \text {; riboflavin, } 5.22 \mathrm{mg} \text {; pantothenic } \\
\text { acid, } 20.0 \mathrm{mg} \text {; niacin, } 26.0 \mathrm{mg} \text {; vitamin } \mathrm{B}_{12}, 0.01 \mathrm{mg} \text {; manganese, } 35.0 \\
\text { mg; iron, } 95.0 \mathrm{mg} \text {; zinc, } 90.0 \mathrm{mg} \text {; copper, } 16.5 \mathrm{mg} \text {; iodine, } 0.30 \mathrm{mg} \text {; } \\
\text { selenium, } 0.30 \mathrm{mg} \text {. }\end{array}$} \\
\hline
\end{tabular}

Experiment 2: Eight barrows (Duroc $\times$ Landrace $\times$ Large White) with a BW of $25.6 \pm 3.2 \mathrm{~kg}$ were used to compare the SID of AA among fish meal, Prosin and Protide. Each pig was surgically fitted with a T-cannula at the distal ileum according to the method described by Stein et al. (1998). After surgery, pigs were transferred to individual pens $(1.8 \times 0.8 \mathrm{~m})$ in a temperature-controlled room $\left(22^{\circ} \mathrm{C}\right)$ where they were allowed to recover for $10 \mathrm{~d}$. A standard diet and water were provided ad libitum during this time (CervantesPahm and Stein, 2010). Pigs were then randomly assigned to a replicated $4 \times 4$ Latin square design. Three diets were formulated to contain each protein ingredient as the only protein and AA source. A N-free diet was also formulated to determine the basal endogenous losses of CP and AA. The three protein-containing diets were formulated to provide the same amount of $\mathrm{CP}(12 \%)$ in each diet. $0.30 \%$ chromic oxide were added to all diets as an indigestible marker (Table 3).

Each feeding period consisted of a 5-d adaptation period followed by $2 \mathrm{~d}$ for collection of ileal digesta. The BW of each pig was recorded at the beginning and the end of each period. Pigs were fed the diets at three times their maintenance energy requirement, based on their BW at the beginning of each period. Feed allowance was divided into two equal meals and fed at 8:00 and 17:00 each day. Ileal digesta were collected continuously for $12 \mathrm{~h}$ from 8:00 to 20:00 h on d 6 and 7 (Stein et al., 1998). A plastic bag was attached to the cannula using a cable tie to collect the digesta. The bags were collected and replaced using a new one at least once every $20 \mathrm{~min}$. Ileal digesta were stored on ice during the 12-h collection period. After each day's collection, digesta were frozen at $-20^{\circ} \mathrm{C}$ to limit microbial activity and $\mathrm{N}$ loss until the end of collection. At the end of
Table 3. Ingredient composition of experimental diets containing fish meal and single-cell proteins (Prosin and Protide) (as-fed basis), Exp. 2

\begin{tabular}{|c|c|c|c|c|}
\hline Ingredient (\%) & $\begin{array}{l}\text { Nitrogen- } \\
\text { free }\end{array}$ & $\begin{array}{c}\text { Fish } \\
\text { meal }^{1}\end{array}$ & Prosin $^{2}$ & Protide $^{2}$ \\
\hline Cornstarch & 70.04 & 67.90 & 66.46 & 63.28 \\
\hline Sucrose & 18.00 & 10.00 & 10.00 & 10.00 \\
\hline Solka floc ${ }^{3}$ & 4.00 & - & - & - \\
\hline Fish meal $(66.03 \% \mathrm{CP})$ & - & 18.11 & - & - \\
\hline Prosin $(70.03 \% \mathrm{CP})$ & - & - & 17.13 & - \\
\hline Protide $(57.53 \% \mathrm{CP})$ & - & - & - & 20.86 \\
\hline Soybean oil & 3.00 & 2.00 & 2.00 & 2.00 \\
\hline Limestone & 0.38 & - & 0.56 & 1.37 \\
\hline Dicalcium phosphate & 3.03 & 0.84 & 2.70 & 1.34 \\
\hline Salt & 0.35 & 0.35 & 0.35 & 0.35 \\
\hline Magnesium oxide & 0.10 & - & - & - \\
\hline Potassium carbonate & 0.30 & - & - & - \\
\hline Chromic oxide & 0.30 & 0.30 & 0.30 & 0.30 \\
\hline $\begin{array}{l}\text { Vitamin-mineral } \\
\text { premix }^{4}\end{array}$ & 0.50 & 0.50 & 0.50 & 0.50 \\
\hline \multicolumn{5}{|c|}{$\begin{array}{l}{ }^{1} \text { Fish meal (Commercial supply). } \\
{ }^{2} \text { Prosin and Protide (CJ Co. Ltd., Liaocheng, China). } \\
{ }^{3} \text { Made by Chemical Reagents Company (Beijing, China). } \\
{ }^{4} \text { Premix supplied per kg diet: vitamin A, 11,000 IU; vitamin } \mathrm{D}_{3}, 1,500 \mathrm{IU} \text {; } \\
\text { vitamin E, } 44.1 \mathrm{IU} \text {; menadione, } 4.0 \mathrm{mg} \text {; riboflavin, } 5.22 \mathrm{mg} \text {; pantothenic } \\
\text { acid, } 20.0 \mathrm{mg} \text {; niacin, } 26.0 \mathrm{mg} \text {; vitamin } \mathrm{B}_{12}, 0.01 \mathrm{mg} \text {; manganese, } 35.0 \\
\text { mg; iron, } 100.0 \mathrm{mg} \text {; zinc, } 90.0 \mathrm{mg} \text {; copper, } 16.5 \mathrm{mg} \text {; iodine, } 0.30 \mathrm{mg} \text {; } \\
\text { selenium, } 0.30 \mathrm{mg} \text {. }\end{array}$} \\
\hline
\end{tabular}

each collection day, ileal samples were thawed, pooled by pig, and a subsample was taken for lyophilization (KarrLilienthal et al., 2004).

Experiment 3: A total of 180 crossbred pigs (Durocx Landrace $\times$ Large White; initial $\mathrm{BW}$ of $7.95 \pm 1.59 \mathrm{~kg}$ ) weaned at $28 \pm 2 \mathrm{~d}$ of age were allocated to one of five dietary treatments on the basis of $\mathrm{BW}$ and gender in a randomized complete block design. Each treatment was fed to six pens with six pigs (three barrows and three gilts) per pen. The five treatments were as follows: the control group $(\mathrm{CON})$ was a corn-soybean meal diet contained $5 \%$ fish meal; the other four treatments replaced fish meal with Prosin (2.5\% or 5\%) or Protide (2.5\% or 5\%), respectively. The diets were formulated to supply identical amounts of ME and SID lysine, methionine, threonine and tryptophan. The SID lysine and ME contents of fish meal, Prosin and Protide and the ME content of corn were obtained according to the data obtained in Exp. 1 and Exp. 2. The ME contents of whey powder $(3,300 \mathrm{kcal} / \mathrm{kg})$, and soybean oil $(8,400 \mathrm{kcal} / \mathrm{kg})$ were obtained from NRC (1998). The SID lysine contents of corn and whey powder were determined previously using pigs surgically equipped with a T-cannula in the distal ileum by our laboratory (data not published). The diets were shown in Table 4 . The pigs were housed in $2 \times 3 \mathrm{~m}$ raised pens equipped with a mesh floor. 
Table 4. Ingredient composition of experimental diets containing fish meal and single-cell proteins (Prosin and Protide) (as-fed basis), Exp. 3

\begin{tabular}{|c|c|c|c|c|c|}
\hline Ingredients (\%) & $\mathrm{CON}^{1}$ & $2.5 \%$ Prosin $^{2}$ & $2.5 \%$ Prosin $^{2}$ & $2.5 \%$ Protide $^{2}$ & $5 \%$ Protide $^{2}$ \\
\hline Corn & 61.54 & 60.88 & 60.23 & 60.31 & 59.06 \\
\hline Soybean meal & 21.59 & 21.61 & 21.64 & 22.10 & 22.64 \\
\hline Fish meal $(66.03 \% \mathrm{CP})$ & 5.00 & 2.50 & - & 2.50 & - \\
\hline Prosin $(70.03 \% \mathrm{CP})$ & - & 2.50 & 5.00 & - & - \\
\hline Protide $(57.53 \% \mathrm{CP})$ & - & - & - & 2.50 & 5.00 \\
\hline Whey powder & 6.00 & 6.00 & 6.00 & 6.00 & 6.00 \\
\hline Soybean oil & 2.14 & 2.47 & 2.79 & 2.52 & 2.88 \\
\hline Dicalcium phosphate & 1.26 & 1.56 & 1.88 & 1.38 & 1.48 \\
\hline Limestone & 0.69 & 0.76 & 0.80 & 0.86 & 1.03 \\
\hline Chromic oxide & 0.25 & 0.25 & 0.25 & 0.25 & 0.25 \\
\hline Salt & 0.35 & 0.35 & 0.35 & 0.35 & 0.35 \\
\hline L-Lys-HCl (78\%) & 0.42 & 0.35 & 0.28 & 0.48 & 0.56 \\
\hline $\mathrm{MHA}^{3}$ & 0.04 & 0.05 & 0.06 & 0.03 & 0.04 \\
\hline L-threonine & 0.17 & 0.17 & 0.17 & 0.17 & 0.17 \\
\hline L-tryptophan & 0.05 & 0.05 & 0.05 & 0.05 & 0.04 \\
\hline Premix $^{4}$ & 0.50 & 0.50 & 0.50 & 0.50 & 0.50 \\
\hline \multicolumn{6}{|c|}{ Nutrient levels, calculated (\%) } \\
\hline $\mathrm{ME}(\mathrm{kcal} / \mathrm{kg})$ & 3,265 & 3,265 & 3,265 & 3,265 & 3,265 \\
\hline $\mathrm{CP}$, analyzed & 19.46 & 19.48 & 19.51 & 19.48 & 19.46 \\
\hline $\mathrm{Ca}$, analyzed & 0.78 & 0.77 & 0.79 & 0.78 & 0.76 \\
\hline $\mathrm{P}$, analyzed & 0.62 & 0.65 & 0.62 & 0.64 & 0.65 \\
\hline SID lysine & 1.20 & 1.20 & 1.20 & 1.20 & 1.20 \\
\hline SID methionine & 0.32 & 0.32 & 0.32 & 0.32 & 0.32 \\
\hline SID threonine & 0.74 & 0.74 & 0.74 & 0.74 & 0.74 \\
\hline SID tryptophan & 0.22 & 0.22 & 0.22 & 0.22 & 0.22 \\
\hline
\end{tabular}

${ }^{1} \mathrm{CON}=$ Fish meal (Commercial supply). ${ }^{2}$ Prosin and Protide (CJ Co. Ltd., Liaocheng, China).

${ }^{3}$ DL-methionine hydroxy analogue $(84 \%)$ provided by Novus International, St. Louis, MO.

${ }^{4}$ Premix supplied per kg diet: vitamin A, 11,500 IU; vitamin $\mathrm{D}_{3}, 1,500 \mathrm{IU}$; vitamin E, $44.1 \mathrm{IU}$; menadione, $4.0 \mathrm{mg}$; riboflavin, $5.22 \mathrm{mg}$; pantothenic acid, $20.0 \mathrm{mg}$; niacin, $26.0 \mathrm{mg}$; vitamin $\mathrm{B}_{12}, 0.01 \mathrm{mg}$; manganese, $35.0 \mathrm{mg}$; iron, $110.0 \mathrm{mg}$; zinc, $95.0 \mathrm{mg}$; copper, $16 \mathrm{mg}$; iodine, $0.30 \mathrm{mg}$; selenium, 0.30 .

The temperature was maintained between 26 and $30^{\circ} \mathrm{C}$. All pigs had free access to feed and water throughout the 4-wk feeding trial.

Pigs and feeders were weighed at the beginning and end of the experiment to determine weight gain, feed intake and feed conversion rate (FCR). From d 26 to 28 of the experiment, approximately $50 \mathrm{~g}$ of feces were collected daily from each pen and the samples were stored at $-20^{\circ} \mathrm{C}$. The three day collection of feces was thawed, pooled by pen and then oven dried at $60^{\circ} \mathrm{C}$ for $72 \mathrm{~h}$ ( $\mathrm{Li}$ et al., 2012). All samples were ground to pass through a $1.0 \mathrm{~mm}$ screen before analysis. On d 28, two pigs from each pen were electronically stunned and killed, and tissue samples from the small intestine were collected immediately. The middle sections of the duodenum, jejunum, and ileum were aseptically isolated, flushed with a $0.9 \%$ salt solution, fixed with $10 \%$ formaldehyde-phosphate buffer, and kept at $4{ }^{\circ} \mathrm{C}$ for microscopic assessment of mucosal morphology (Liu et al., 2010).

\section{Analytical assays}

Analyses for DM, CP, Ca, and total phosphorus in diets and feces were conducted according to the methods of AOAC (2000). Gross energy was determined using an automatic adiabatic oxygen bomb calorimeter (Parr 1281 Automatic Energy Analyzer, Moline, IL). The chromium content in the diets and digesta was measured using an Atomic Absorption Spectrophotometer (Hitachi Z-5000 Automatic Absorption Spectrophotometer, Tokyo, Japan) according to the procedure of Williams et al. (1962).

The AA content in the diets and digesta were assayed using ion-exchange chromatography with an Automatic Amino Acid Analyzer (L-8800 Hitachi Automatic Amino Acid Analyzer, Tokyo, Japan) after hydrolyzing with 6 $\mathrm{mol} / \mathrm{L} \mathrm{HCl}$ at $110^{\circ} \mathrm{C}$ for $24 \mathrm{~h}$. Cystine was determined as cysteic acid and methinonine as methionine sulfone after preoxidation with performic acid and pre-column derivation using phenylisothiocyanate (L-8800 Hitachi Automatic Amino Acid Analyzer, Tokyo, Japan). Tryptophan was determined after hydrolyzing with $4 \mathrm{~mol} / \mathrm{L} \mathrm{NaOH}$ at $110^{\circ} \mathrm{C}$ 
Table 5. The DE and ME contents in fish meal and single-cell proteins (Prosin and Protide) (as-fed basis), Exp. $1^{1}$

\begin{tabular}{|c|c|c|c|c|c|}
\hline Item & Fish meal $^{2}$ & Prosin $^{3}$ & Protide $^{3}$ & SEM & $\mathrm{p}$-value \\
\hline \multicolumn{6}{|l|}{ DM basis } \\
\hline DE in ingredients $(\mathrm{kcal} / \mathrm{kg})$ & $3,603^{\mathrm{a}}$ & $3,234^{\mathrm{b}}$ & $3,156^{\mathrm{b}}$ & 35.34 & $<0.001$ \\
\hline ME in ingredients $(\mathrm{kcal} / \mathrm{kg})$ & $3,143^{\mathrm{a}}$ & $2,878^{\mathrm{b}}$ & $2,777^{\mathrm{b}}$ & 38.16 & $<0.001$ \\
\hline \multicolumn{6}{|l|}{ Fed basis } \\
\hline $\mathrm{DE}$ in ingredient $(\mathrm{kcal} / \mathrm{kg})$ & $3,243^{\mathrm{a}}$ & $3,047^{\mathrm{b}}$ & $3,029^{\mathrm{b}}$ & 39.63 & 0.008 \\
\hline ME in ingredient $(\mathrm{kcal} / \mathrm{kg})$ & $2,829^{\mathrm{a}}$ & $2,712^{\mathrm{ab}}$ & $2,665^{\mathrm{b}}$ & 42.77 & 0.031 \\
\hline
\end{tabular}

${ }^{1}$ Data are the means of eight pigs (initial BW of $30.8 \pm 2.6 \mathrm{~kg}$ ). ${ }^{2}$ Fish meal (Commercial supply). ${ }^{3}$ Prosin and Protide (CJ Co. Ltd., Liaocheng, China).

${ }^{\mathrm{a}, \mathrm{b}}$ Means in the same row with different superscripts are significantly different $(\mathrm{p}<0.05)$.

for $22 \mathrm{~h}$ using phenylisothiocyanate (Model 76337, Agilent Technologics, Waldbronn, Germany).

Histological measurements were conducted according to the procedures described by Shen et al. (2009). Briefly, formalin-fixed intestinal samples were prepared using paraffin embedding techniques. Samples were sectioned at a $6 \mu \mathrm{m}$ thickness and stained with hematoxylin and eosin. Villus height and crypt depth were then measured at $40 \times$ magnification with a microscope (CK40, Olympus Optical Company, Shenzhen, China). At least 10 well-oriented and intact villi were selected from each pig to measure crypt depth and villus height.

\section{Statistical analysis}

All data were analyzed using SAS (SAS inst. Inc., Cary, NC). In Exp. 1 and Exp. 2, data were analyzed using the Proc-Mixed procedure of SAS with each replicate as the experimental unit. The statistical model for the DE, ME, and SID of AA values had treatment as a fixed effect, period and pig as random effects. In Exp. 3, all data were analyzed as a randomized complete block design with pen as the experimental unit using the GLM procedure. Results were expressed as least squares means and standard error of the mean (SEM). Statistical significance was taken at $\mathrm{p}<0.05$.

\section{RESULTS}

\section{Chemical characteristics}

The DM content in Prosin and Protide was higher than that of fish meal (Table 1). Prosin had higher CP than fish meal, but CP was lowest in Protide. Fish meal contained higher $\mathrm{Ca}$ and P. For essential AA, Prosin (8.23\%) contained higher lysine content than fish meal $(4.97 \%)$ and Protide (1.97\%), but fish meal (1.63\%) and Protide (1.47\%) contained higher methionine than Prosin $(0.98 \%)$; The concentrations of other essential AA were similar among different protein sources, except for histidine, which was higher in fish meal $(2.34 \%)$ than those of Prosin $(1.26 \%)$ and Protide $(0.96 \%)$.

Experiment 1: On DM basis, both of the DE and ME contents were lower in Prosin (3,234 and 2,878 kcal/kg) and Protide $(3,156$ and $2,777 \mathrm{kcal} / \mathrm{kg})$ than that of fish meal
$(3,603$ and 3,143 kcal/kg) ( $\mathrm{p}<0.05$; Table 5). On a fed basis, the DE content for fish meal $(3,243 \mathrm{kcal} / \mathrm{kg})$ was greater than those of Prosin $(3,047 \mathrm{kcal} / \mathrm{kg})$ and Protide $(3,029$ $\mathrm{kcal} / \mathrm{kg})(\mathrm{p}<0.05)$; The fish meal $(2,829 \mathrm{kcal} / \mathrm{kg})$ had higher ME content than Protide $(2,665 \mathrm{kcal} / \mathrm{kg})(\mathrm{p}<0.05)$, but the ME content in Prosin $(2,712 \mathrm{kcal} / \mathrm{kg})$ did not differ from fish meal or Protide.

Experiment 2: The SID of CP $(85.87 \%)$ was greater in fish meal than in Prosin $(80.25 \%)$ and Protide $(81.03 \%)$ $(\mathrm{p}<0.05)$ (Table 6). For essential AA, the SID for all AA in fish meal were greater than in Prosin and Protide $(\mathrm{p}<0.05)$, but no significant differences were found between Prosin

Table 6. SID of CP and AA in fish meal and single-cell proteins (Prosin and Protide), Exp. $2^{1}$

\begin{tabular}{lccccc}
\hline Item & $\begin{array}{c}\text { Fish } \\
\text { meal }^{2}\end{array}$ & Prosin $^{3}$ & Protide $^{3}$ & SEM & p-value \\
\hline CP $(\%)$ & $85.87^{\mathrm{a}}$ & $80.25^{\mathrm{b}}$ & $81.03^{\mathrm{b}}$ & 1.52 & 0.031 \\
Essential AA (\%) & & & & & \\
Arginine & $93.50^{\mathrm{a}}$ & $85.97^{\mathrm{b}}$ & $87.24^{\mathrm{b}}$ & 0.91 & 0.019 \\
Histidine & $84.86^{\mathrm{a}}$ & $78.07^{\mathrm{b}}$ & $78.31^{\mathrm{b}}$ & 0.51 & 0.023 \\
Isoleucine & $88.36^{\mathrm{a}}$ & $80.65^{\mathrm{b}}$ & $81.27^{\mathrm{b}}$ & 1.14 & 0.030 \\
Leucine & $88.92^{\mathrm{a}}$ & $79.09^{\mathrm{b}}$ & $75.86^{\mathrm{b}}$ & 1.55 & 0.019 \\
Lysine & $87.37^{\mathrm{a}}$ & $79.04^{\mathrm{b}}$ & $81.59^{\mathrm{b}}$ & 0.60 & 0.005 \\
Methionine & $89.99^{\mathrm{a}}$ & $84.24^{\mathrm{b}}$ & $83.35^{\mathrm{b}}$ & 0.95 & 0.030 \\
Phenylalanine & $89.65^{\mathrm{a}}$ & $83.95^{\mathrm{b}}$ & $81.52^{\mathrm{b}}$ & 0.98 & 0.021 \\
Threonine & $85.78^{\mathrm{a}}$ & $78.73^{\mathrm{b}}$ & $78.14^{\mathrm{b}}$ & 0.84 & 0.031 \\
Tryptophan & $87.38^{\mathrm{a}}$ & $81.86^{\mathrm{b}}$ & $82.99^{\mathrm{b}}$ & 0.35 & 0.003 \\
Valine & $86.88^{\mathrm{a}}$ & $79.31^{\mathrm{b}}$ & $78.78^{\mathrm{b}}$ & 0.82 & 0.010 \\
Nonessential AA $(\%)$ & & & & \\
Alanine & $88.56^{\mathrm{a}}$ & $82.00^{\mathrm{b}}$ & $77.99^{\mathrm{c}}$ & 0.66 & \\
Asparagine & $80.91^{\mathrm{a}}$ & $73.94^{\mathrm{b}}$ & $76.11^{\mathrm{b}}$ & 0.68 & 0.004 \\
Cystine & 77.68 & 72.89 & 73.52 & 1.39 & 0.012 \\
Glutamine & $82.43^{\mathrm{a}}$ & $77.70^{\mathrm{b}}$ & $76.22^{\mathrm{b}}$ & 0.68 & 0.163 \\
Glycine & $84.00^{\mathrm{a}}$ & $78.06^{\mathrm{b}}$ & $76.93^{\mathrm{b}}$ & 1.05 & 0.016 \\
Proline & $113.59^{\mathrm{c}}$ & $140.20^{\mathrm{a}}$ & $124.58^{\mathrm{b}}$ & 1.09 & 0.033 \\
Serine & $82.53^{\mathrm{a}}$ & $78.09^{\mathrm{b}}$ & $69.81^{\mathrm{c}}$ & 0.63 & 0.001 \\
Tyrosine & $87.74^{\mathrm{a}}$ & $76.96^{\mathrm{b}}$ & $78.72^{\mathrm{b}}$ & 0.98 & 0.002 \\
\hline
\end{tabular}

${ }^{1}$ Data are the means of eight pigs (initial BW of $25.6 \pm 3.2 \mathrm{~kg}$ ) used in a replicated $4 \times 4$ Latin square design.

${ }^{2}$ Fish meal (Commercial supply).

${ }^{3}$ Prosin and Protide (CJ Co. Ltd., Liaocheng, China).

a,b,c Means in the same row with different superscripts are significantly different $(\mathrm{p}<0.05)$. 
Table 7. Effects of single-cell proteins (Prosin and Protide) replacing fish meal in diet on growth performance of weaned piglets, Exp. $3^{1}$

\begin{tabular}{|c|c|c|c|c|c|c|c|}
\hline \multirow{2}{*}{ Item } & \multirow{2}{*}{$\begin{array}{c}\text { Fish meal }(\%) \\
5\end{array}$} & \multicolumn{2}{|c|}{$\operatorname{Prosin}^{3}(\%)$} & \multicolumn{2}{|c|}{$\operatorname{Protide}^{3}(\%)$} & \multirow{2}{*}{ SEM } & \multirow{2}{*}{$\mathrm{p}$-value } \\
\hline & & 2.5 & 5 & 2.5 & 5 & & \\
\hline$\overline{\mathrm{ADG}}(\mathrm{g} / \mathrm{d})$ & $370^{\mathrm{a}}$ & $354^{\mathrm{ab}}$ & $339^{\mathrm{bc}}$ & $363^{\mathrm{ab}}$ & $343^{\mathrm{bc}}$ & 9.12 & 0.019 \\
\hline $\operatorname{ADFI}(\mathrm{g} / \mathrm{d})$ & 528 & 518 & 538 & 539 & 531 & 12.63 & 0.876 \\
\hline FCR & $1.44^{\mathrm{c}}$ & $1.47^{\mathrm{bc}}$ & $1.59^{\mathrm{ab}}$ & $1.49^{\mathrm{bc}}$ & $1.56^{\mathrm{ab}}$ & 0.05 & 0.018 \\
\hline
\end{tabular}

${ }^{1} \mathrm{~A}$ total of 180 pigs (initial BW of $7.95 \pm 1.59 \mathrm{~kg}$ and $28 \pm 2 \mathrm{~d}$ of age) were allotted to provide six pigs per pen and six pens per treatment.

${ }^{2}$ Fish meal (Commercial supply). ${ }^{3}$ Prosin and Protide (CJ Co. Ltd., Liaocheng, China).

${ }_{a, b, c}$ Means in the same row with different superscripts are significantly different $(\mathrm{p}<0.05)$.

Table 8. Effects of single-cell proteins (Prosin and Protide) replacing fish meal in diet on nutrient digestibility of weaned piglets, Exp. $3^{1}$

\begin{tabular}{|c|c|c|c|c|c|c|c|}
\hline \multirow{2}{*}{ Item $(\%)$} & \multirow{2}{*}{$\begin{array}{c}\text { Fish meal }^{2}(\%) \\
5\end{array}$} & \multicolumn{2}{|c|}{$\operatorname{Prosin}^{3}(\%)$} & \multicolumn{2}{|c|}{ Protide $^{3}(\%)$} & \multirow{2}{*}{ SEM } & \multirow{2}{*}{ p-value } \\
\hline & & 2.5 & 5 & 2.5 & 5 & & \\
\hline$\overline{\mathrm{DM}}$ & 86.51 & 85.30 & 84.60 & 85.95 & 85.54 & 0.60 & 0.356 \\
\hline Gross energy & 86.79 & 86.77 & 87.00 & 86.16 & 86.67 & 0.64 & 0.817 \\
\hline $\mathrm{CP}$ & $85.15^{\mathrm{a}}$ & $83.74^{\mathrm{a}}$ & $81.28^{\mathrm{b}}$ & $84.17^{\mathrm{a}}$ & $81.17^{\mathrm{b}}$ & 0.73 & $<0.001$ \\
\hline $\mathrm{P}$ & 59.89 & 59.70 & 58.72 & 59.99 & 59.37 & 1.28 & 0.944 \\
\hline $\mathrm{Ca}$ & 67.11 & 67.88 & 66.98 & 67.36 & 67.24 & 1.14 & 0.994 \\
\hline
\end{tabular}

${ }^{1}$ A total of 180 pigs (initial BW of $7.95 \pm 1.59 \mathrm{~kg}$ and $28 \pm 2 \mathrm{~d}$ of age) were allotted to provide six pigs per pen and six pens per treatment.

${ }^{2}$ Fish meal (Commercial supply). ${ }^{3}$ Prosin and Protide (CJ Co. Ltd., Liaocheng, China).

${ }^{\mathrm{a}, \mathrm{b}}$ Means in the same row with different superscripts are significantly different $(\mathrm{p}<0.05)$.

and Protide. For nonessential AA, the SID of most AA was greater in fish meal than in Prosin and Protide, except for cystine and proline $(\mathrm{p}<0.05)$. Prosin and Protide had greater SID of proline than fish meal $(\mathrm{p}<0.05)$, but no significant differences were found in cystine among fish meal, Prosin and Protide.

Experiment 3: The pigs fed CON diet contained 5\% fish meal had greater weight gain than pigs fed 5\% Prosin and $5 \%$ Protide diets $(\mathrm{p}<0.05)$ (Table 7), but no differences were observed in weight gain among pigs fed $\mathrm{CON}, 2.5 \%$ Prosin or $2.5 \%$ Protide diets. Pigs fed the CON diet had lower FCR than pigs fed $5 \%$ Prosin and Protide diets $(\mathrm{p}<0.05)$. The
ADFI was not different among treatments.

The digestibility of $\mathrm{CP}$ was greater in pigs fed CON, $2.5 \%$ Prosin and $2.5 \%$ Protide diets than the pigs fed $5 \%$ Prosin and $5 \%$ Protide diets $(\mathrm{p}<0.05)$ (Table 8$)$, but no differences were observed among pigs fed CON, $2.5 \%$ Prosin or $2.5 \%$ Protide diets. The digestibility of DM, gross energy, $\mathrm{Ca}$ and $\mathrm{P}$ was not affected by dietary protein sources.

No dietary effects were found in crypt depth of the duodenum, jejunum and ileum among treatments (Table 9). Villus height in jejunum and ileum, and villus height to crypt depth ratio in the jejunum were higher $(\mathrm{p}<0.05)$ in pigs fed the CON, 2.5\% Prosin and $2.5 \%$ Protide diets

Table 9. Effects of single-cell proteins (Prosin and Protide) replacing fish meal in diet on intestinal morphology of weaned piglets, Exp. $3^{1}$

\begin{tabular}{|c|c|c|c|c|c|c|c|}
\hline \multirow{2}{*}{ Item } & \multirow{2}{*}{$\frac{\text { Fish meal }^{2}(\%)}{5}$} & \multicolumn{2}{|c|}{$\operatorname{Prosin}^{3}(\%)$} & \multicolumn{2}{|c|}{$\operatorname{Protide}^{3}(\%)$} & \multirow{2}{*}{ SEM } & \multirow{2}{*}{ p-value } \\
\hline & & 2.5 & 5 & 2.5 & 5 & & \\
\hline \multicolumn{8}{|l|}{ Duodenum } \\
\hline Villus height $(\mu \mathrm{m})$ & 424 & 425 & 429 & 412 & 426 & 7.02 & 0.569 \\
\hline Crypt depth $(\mu \mathrm{m})$ & 204 & 196 & 200 & 203 & 197 & 4.20 & 0.533 \\
\hline Villus height to crypt depth ratio & 2.08 & 2.17 & 2.15 & 2.03 & 2.17 & 0.04 & 0.236 \\
\hline \multicolumn{8}{|l|}{ Jejunum } \\
\hline Villus height $(\mu \mathrm{m})$ & $359^{\mathrm{a}}$ & $352^{\mathrm{a}}$ & $323^{\mathrm{b}}$ & $348^{\mathrm{a}}$ & $321^{\mathrm{b}}$ & 7.16 & 0.001 \\
\hline Crypt depth $(\mu \mathrm{m})$ & 183 & 182 & 180 & 183 & 187 & 3.13 & 0.906 \\
\hline Villus height to crypt depth ratio & $1.97^{\mathrm{a}}$ & $1.95^{\mathrm{a}}$ & $1.77^{\mathrm{b}}$ & $1.91^{\mathrm{a}}$ & $1.72^{\mathrm{b}}$ & 0.05 & 0.002 \\
\hline \multicolumn{8}{|l|}{ Ileum } \\
\hline Villus height $(\mu \mathrm{m})$ & $486^{\mathrm{a}}$ & $478^{\mathrm{a}}$ & $415^{\mathrm{b}}$ & $477^{\mathrm{a}}$ & $420^{\mathrm{b}}$ & 7.59 & 0.001 \\
\hline Crypt depth $(\mu \mathrm{m})$ & 190 & 205 & 200 & 203 & 193 & 7.14 & 0.746 \\
\hline Villus height to crypt depth ratio & $2.56^{\mathrm{a}}$ & $2.34^{\mathrm{ab}}$ & $2.09^{\mathrm{c}}$ & $2.39^{\mathrm{ab}}$ & $2.18^{\mathrm{bc}}$ & 0.08 & 0.001 \\
\hline
\end{tabular}

${ }^{1}$ A total of 180 pigs (initial BW of $7.95 \pm 1.59 \mathrm{~kg}$ and $28 \pm 2 \mathrm{~d}$ of age) were allotted to provide six pigs per pen and six pens per treatment.

${ }^{2}$ Fish meal (Commercial supply). ${ }^{3}$ Prosin and Protide (CJ Co. Ltd., Liaocheng, China).

${ }^{a, b, c}$ Means in the same row with different superscripts are significantly different $(\mathrm{p}<0.05)$. 
compared with the 5\% Prosin and 5\% Protide diets. Pigs fed CON diet had greater villus height to crypt depth ratio in the ileum than the pigs fed 5\% Prosin and 5\% Protide diets $(\mathrm{p}<0.05)$, but villus height to crypt depth ration of the CON group was not different from the pigs fed $2.5 \%$ Prosin and $2.5 \%$ Protide diets.

\section{DISCUSSION}

The concentrations of $\mathrm{CP}$ and $\mathrm{AA}$ in fish meal were similar to those reported by NRC (1998) and Kim and Easter (2001). The CP and AA profile of Prosin was similar to that shown earlier for SCP (Aas et al., 2006), but Prosin contained higher level of lysine, alanine and glutamine, and lower level of methionine and tyrosine. Additionally, the Protide had similar AA profile with Prosin, but it contained lower level of CP, lysine and histidine, and higher level of methionine and tryptophan than that of Prosin. The differences between Prosin and Protide may mainly be because the Prosin and Protide are byproducts of lysine and nucleotide production, respectively, and the SCP produced by different processing technology may cause different nutritional properties which may also influence its utilization by animals (Hellwing et al., 2007a, b). The results of nutritional composition also showed that most essential AA in Prosin and Protide was similar with fish meal, except for lysine and methionine, with Prosin having higher lysine content than fish meal and Protide, but fish meal and Protide contained higher methionine than Prosin. This indicated that the Prosin used in current study contained similar nutritional composition with fish meal, but the AA profile of Prosin is less balanced than fish meal.

From the results in Exp. 1, we can see that the DE and ME contents of fish meal both as fed and DM basis measured in this experiment were slightly greater than the values reported by NRC (1998). Although the GE content of fish meal was lower than Prosin and Protide, the DE and ME contents of fish meal as DM basis were significant higher than Prosin and Protide. This reflected that the energy utilization of fish meal is higher than Prosin and Protide, but no significant differences were found in ME or DE contents between Prosin and Protide. As far as we know, data on DE and ME contents of SCP were limited. Therefore, the values obtained in the present study for Prosin and Protide could reasonably be used to formulate diets in pig production.

The results of Exp. 2 showed that the SID of CP was $85.78 \%$, and the SID of essential AA in fish meal ranged from $84.86 \%$ for histidine and arginine to $93.5 \%$, which was similar to the SID values reported by Urbaityte et al. (2009) and Cervantes-Pahm and Stein (2010). The SID of $\mathrm{CP}$ and essential AA obtained for Prosin and Protide ranged from $75.86 \%$ for leucine of Protide to $87.24 \%$ for arginine of Protide, which were close to the values for SCP obtained in growing pigs by Wang et al. (2013), but Prosin and Protide used in current study had greater SID of arginine, lower SID of lysine. The SID of CP and essential AA of Prosin and Protide were significant lower than fish meal, which indicated that although most essential AA in Prosin and Protide was similar with fish meal (results in Table 1), the AA utilization was worse than fish meal. Skrede et al. (1998) suggested that $\mathrm{N}$ digestibility was influenced by digestibility of nucleic acids and other non-protein constituents in SCP. The lower digestibility for SCP may result from its higher non-protein nitrogen (e.g., nucleotides content), which is poorly used by swine (Wang et al., 2013). SCP contains approximately $10 \%$ nucleic acids, mostly as RNA (Skrede et al., 1998), the RNA and DNA contents are much higher than those found in fish meal, for instance (Greife, 1984). Therefore, the high nucleic acids contents may be the reason for decreased AA digestibility of Prosin and Protide.

In Exp. 3, the results of performance showed that the full replacement of fish meal protein by Prosin and Protide significantly decreased the performance of weaned piglets, even though all the nutrients were kept consistent among diets. This was consistent with the previous result from Øverland et al. (2004) who suggested that replacing soybean meal with $5 \%, 10 \%$, or $15 \%$ SCP in diets containing identical ME, available lysine, methionine and threonine reduced the growth performance of pigs linearly during the piglet period, but had no adverse effect on growing-finishing or overall period growth performance of pig. Furthermore, Øverland et al. (2001) reported that feeding diets in which the SCP replaced $50 \%$ of the lysine in soybean meal (low SCP diets containing either 30 or 52 $\mathrm{g} / \mathrm{kg} \mathrm{SCP}$ ) did not affect growth performance during the growing period. This indicated that more amounts of protein can be replaced by SCP in growing or finishing pigs' diet than that of weaned piglets' diet; an inclusion of a certain level of SCP in weaned piglets' diet is feasible, because the results obtained from our study showed that $50 \%$ replacement of fish meal protein with Prosin or Protide in diets containing identical nutrient levels did not affect the performance of weaned piglets.

The reason for decreased performance in pigs fed the $5 \%$ Prosin or 5\% Protide diet may be partly due to the decreased digestibility of CP observed in our study, but it was similar among the pigs fed 5\% fish meal, 2.5\% Prosin and $2.5 \%$ Protide diets. The higher inclusion of Prosin and Protide in diet could decrease the digestibility of CP. This was consistent with the study in grower-finisher pigs observed by Zhao et al. (2012) who suggested that the nitrogen metabolism in growing-finishing pigs was 
unaffected when $25 \%$ of dietary soybean protein was replaced by SCP, but the nitrogen digestibility of $50 \%$ replacement group was $5 \%$ lower during the growing period and $3 \%$ lower during the finishing period than that of $\mathrm{CON}$ group. Aas et al. (2006) also showed that the apparent digestibility of nitrogen, sum of amino acids decreased as dietary SCP levels increased.

The morphological changes in the intestine would be followed by a change in nutrient digestion and absorption (Pluske et al., 1997), therefore, the villus height to crypt depth ratio of small intestine would affect the nutrient digestibility and absorption capacity (Montagne et al., 2003). In the current study, the digestibility of CP was decreased significantly when replaced $100 \%$ of fish meal with Prosin or Protide in weaned pig's diets. We also observed that the villus height to crypt depth ratio in the jejunum was significantly decreased in the pigs fed $5 \%$ Prosin and 5\% Protide diets compared with the pigs fed CON, 2.5\% Prosin and 2.5\% Protide diets. But pigs fed CON diet had a greater villus height to crypt depth ratio in ileum than the pigs fed 5\% Prosin and 5\% Protide diets. This demonstrated that full replacement of fish meal with Prosin or Protide in diet decreased villus height and villus height to crypt depth ratio in the jejunum and ileum, resulted in lower digestibility of $\mathrm{CP}$, and reduced the growth performance of weaned piglets.

Our findings suggest that although Prosin and Protide contained lower ME content and SID of AA than fish meal, Prosin and Protide replacing 50\% of fish meal in diet with identical nutrient levels could obtain similar performance, nutrient digestibility and intestinal morphology in weaned pigs.

\section{ACKNOWLEDGEMENTS}

The financial support was received from the National Natural Science Foundation of China (No.31072040), the Ministry of Science and Technology of China (No.2013BAD10B04). We thank CJ International for supplying lysine and threonine, and Novus International for supplying the methionine hydroxyl analogue.

\section{REFERENCES}

Aas, T. S., B. Grisdale-Helland, B. F. Terjesen, and S. J. Helland. 2006. Improved growth and nutrient utilisation in Atlantic salmon (Salmo salar) fed diets containing a bacterial protein meal. Aquaculture 259:365-376.

Adeola, O. and N. L. Bajjalieh. 1997. Energy concentration of high-oil corn varieties for pigs. J. Anim. Sci. 75:430-436.

Anupama, P. and L. Ravindra, 2000. Value-added food: single cell protein. Biotechnol. Adv. 18:459-479.

AOAC. 2000. Official methods of analysis, 17th ed. Association of
Official Analytical Chemists, Arlington, VA.

Berge, G. M., G. Baeverf jord, A. Skrede, and T. Storebakken. 2005. Bacterial protein grown on natural gas as protein source in diets for Atlantic salmon, Salmo salar, in saltwater. Aquaculture 244:233-240.

Braude, R., Z. D. Hosking, K. D. MitchellI, S. Plonka, and I. E. Sambrook. 1977. Pruteen, a new source of protein for growing pigs. I. Metabolic experiment: Utilization of nitrogen. Livest. Prod. Sci. 4:79-89.

Cervantes-Pahm, S. K. and H. H. Stein. 2010. Ileal digestibility of amino acids in conventional, fermented, and enzyme-treated soybean meal and in soy protein isolate, fish meal, and casein fed to weanling pig. J. Anim. Sci. 88:2674-2683.

Greife, H. A. 1984. Die Nukleinsäuren - ein gesundheitlicher Risikofaktor beim Einsatz von "Single-Cell Protein" in der Tierernährung? (Teil 1). Kraftfutter. 67:412-414.

Hanssen, J. T. and L. Farstad. 1980. Effects of feeding large amounts of "Pruteen" and "Toprina" on some biological parameters in growing finishing pigs. Acta Agric. Scand. 30:74-80.

Hellwing, A. L. F., A. H. Tauson, Ø. Ahlstrøm, and A. Skrede. 2005. Nitrogen and energy balance in growing mink (Mustela vison) fed different levels of bacterial protein meal produced with natural gas. Arch. Anim. Nutr. 59:335-352.

Hellwing, A. L. F., A. H. Tauson, and A. Skrede. 2006. Effect of bacterial protein meal on protein and energy metabolism in growing chickens. Arch. Anim. Nutr. 60:365-381.

Hellwing, A. L. F., A. H. Tauson, A. Skrede, and N. P. Kjos. 2007a. Bacterial protein meal- effects on protein and energy metabolism in pigs. Animal 1:45-54.

Hellwing, A. L. F., A. H. Tauson, A. Skrede, N. P. Kjos, and $\varnothing$. Ahlstrøm. 2007b. Bacterial protein meal in diets for pigs and minks: Comparative studies on protein turnover rate and urinary excretion of purine base derivatives. Arch. Anim. Nutr. 61:425-443.

Karr-Lilienthal, L. K., N. R. Merchen, C. M. Grieshop, M. A. Flahaven, D. C. Mahan, N. D. Fastinger, M. Watts, and G. C. Fahey, Jr. 2004. Ileal amino acid digestibilities by pigs fed soybean meals from five major soybean-producing countries. J. Anim. Sci. 82:3198-3209.

Kim, S. W. and R. A. Easter. 2001. Nutritional value of fish meals in the diets for young pigs. J. Anim. Sci. 79:1829-1839.

Kuhad, R. C., A. Singh, K. K. Tripathi, R. K. Saxena, and K. E. L. Eriksson. 1997. Microorganisms as an alternative source of protein. Nutr. Rev. 55:65-75.

Li, P. F., X. S. Piao, Y. J. Ru, X. Han, L. F. Xue, and H. Y. Zhang. 2012. Effects of adding essential oil to the diet of weaned pigs on performance, nutrient utilization, immune response and intestinal health. Asian-Aust. J. Anim. Sci. 25:1617-1626.

Liu, P., X. S. Piao, P. A. Thacker, Z. K. Zeng, P. F. Li, D. Wang, and S. W. Kim. 2010. Chito-oligosaccharide reduces diarrhea incidence and attenuates the immune response of weaned pigs challenged with Escherichia coli k88. J. Anim. Sci. 88:38713879 .

Montagne, L., J. R. Pluske, and D. J. Hampson. 2003. A review of interactions between dietary fibre and the intestinal mucosa, and their consequences on digestive health in young nonruminant animals. Anim. Feed Sci. Technol. 108:95-117. 
NRC. 1998. Nutrient requirements of swine, 10th ed. National Academy Press, Washington, DC.

Øverland, M., S. Skrede, and T. Matre. 2001. Bacterial protein grown on natural gas as feed for pigs. Acta. Agric. Scand. A. Anim. Sci. 51:97-106.

Øverland, M., N. P. Kjos, and A. Skrede. 2004. Effect of bacterial protein meal grown on natural gas on growth performance and carcass traits of pigs. Ital. J. Anim. Sci. 3:323-336.

Paraskevopoulou, A., I. Athanasiadis, M. Kanellaki, A. Bekatorou, G. Blekas, and V. Kiosseogloua. 2003. Functional properties of single cell protein produced by kefir microflora. Food Res. Int. $36: 431-438$

Petersen, G. I. and H. H. Stein. 2006. Novel procedure for estimating endogenous losses and measuring apparent and true digestibility of phosphorus by growing pigs. J. Anim. Sci. 84:2126-2132.

Pluske, J. R., D. J. Hampson, and I. H. Williams. 1997. Factors influencing the structure and function of the small intestine in the weaned pig: A review. Livest. Prod. Sci. 51:215-236.

SAS. 1999. SAS user's guide: Statistics (Version 8.01). SAS Inst. Inc., Cary, NC, USA.

Shen, Y. B., X. S. Piao, S. W. Kim, L. Wang, P. Liu, I. Yoon, and Y. G. Zhen. 2009. Effects of yeast culture supplementation on growth performance, intestinal health, and immune response of nursery pigs. J. Anim. Sci. 87:2614-2624.

Skrede, A., T. Storebeakken, G. M. Berge, O. Herstad, K. G Aarstad, and F. Sundstøl. 1998. Digestibility of bacterial protein (BioProtein) grown on natural gas in mink, pigs, chicken and Atlantic salmon. Anim. Feed Sci. Technol. 76:103-116.
Stein, H. H., C. F. Shipley, and R. A. Easter. 1998. Technical note: A technique for inserting a T-cannula into the distal ileum of pregnant sows. J. Anim. Sci. 76:1433-1436.

Urbaityte, R., R. Mosenthin, M. Eklund, H. Piepho, N. Sauer, and M. Rademacher. 2009. Standardised ileal crude protein and amino acid digestibilities in protein supplements for piglets. Arch. Anim. Nutr. 63:356-378.

Wang, J. P., J. D. Kim, J. E. Kim, and I. H. Kim. 2013. Amino acid digestibility of single cell protein from Corynebacterium ammoniagenes in growing pigs. Anim. Feed Sci. Technol. 180:111-114.

Williams, C. H., D. J. David, and O. Iismaa. 1962. The determination of chromic oxide in faeces sample by atomic absorption spectrophotometry. J. Agric. Sci. 59:381-385.

Woodworth, J. C., M. D. Tokach, R. D. Goodband, J. L. Nelssen, P R. O' Quinn, D. A. Knabe, and N. W. Said. 2001. Apparent ileal digestibility of amino acids and the digestible and metabolizable energy content of dry extruded-expelled soybean meal and its effects on growth performance of pigs. J. Anim. Sci. 79:1280-1287.

Zepka, L. Q., E. Jacob-Lopes, R. Goldbeck, L. A. Souza-Soares, and M. I. Queiroz. 2010. Nutritional evaluation of single-cell protein produced by Aphanothece microscopica Nägeli. Bioresour. Technol. 101:7107-7111.

Zhao, Y., B. Yu, X. B. Mao, J. He, Z. Q. Huang, Q. Mao, and D. W. Chen. 2012. Effect of dietary bacterial lysine by-product meal supplementation on growth performance and excretion of purine base derivatives in growing-finishing pig. Livest. Sci. 149:18-24. 